\title{
Growth and grazing rates of the heterotrophic dinoflagellates Protoperidinium spp. on red tide dinoflagellates
}

\author{
Hae Jin Jeong ${ }^{1}$, Michael I. Latz ${ }^{2}$ \\ 'Marine Life Research Group, Scripps Institution of Oceanography, University of California San Diego, La Jolla, \\ California 92093-0218, USA \\ ${ }^{2}$ Marine Biology Research Division 0202, Scripps Institution of Oceanography, University of California San Diego, La Jolla,
} California 92093-0202, USA

\begin{abstract}
Growth and ingestion rates of the heterotrophic dinoflagellates Protoperidinium cf. divergens and $P$. crassipes feeding on red tide dinoflagellates local to southern California, USA, were measured in the laboratory. Unialgal diets of the larger dinoflagellates Gonyaulax polyedra and Gymnodinium sanguineum supported population growth, while the smaller dinoflagellates Prorocentrum cf. balticum and Scrippsiella trochoidea did not; G. polyedra was the optimal diet. The maximum specific growth rates of $P$. cf. divergens and $P$. crassipes on a $G$. polyedra diet were 0.484 and $0.308 \mathrm{~d}^{-1}$, respectively. Specific growth rate increased with mean prey concentration, with saturation at approximately 760 to 1500 cells ml ${ }^{-1}$ Maximum ingestion and clearance rates of $P$. cf, divergens and $P$. crassipes fed on $G$. polyedra were 0.2 and 0.08 prey Protoperidinium ${ }^{-1} \mathrm{~h}^{-1}$, and 0.67 and $0.47 \mu \mathrm{l}$ Protoperidinium ${ }^{-1}$ $\mathrm{h}^{-1}$, respectively. For a $G$. sanguineum diet, the pattern of specific growth rate as a function of mean prey concentration was quite different from that of $G$. polyedra. Maximum specific growth rates were 0.246 and $0.107 \mathrm{~d}^{-1}$ for $P$. cf. divergens and $P$. crassipes at mean prey concentrations of 530 to 1100 cells $\mathrm{ml}^{-1}$. Growth was negative at higher $G$. sanguineum concentrations, and dead Protoperidinium were observed. P. cf. divergens selected G. polyedra over G. sanguineum. Cannibalism was observed in cultures mainly when Protoperidinium abundances were high, and may be a mechanism for withstanding prolonged starvation. The estimated ingestion rate of Protoperidinium during a $G$. polyedra red tide is $\leq 4800$ prey ingested $\mathrm{l}^{-1} \mathrm{~h}^{-1}$, so Protoperidinium may have a considerable grazing impact on some red tide dinoflagellate populations.
\end{abstract}

KEY WORDS: Dinoflagellate $\cdot$ Feeding $\cdot$ Microzooplankton $\cdot$ Plankton $\cdot$ Protozoa $\cdot$ Red tide

\section{INTRODUCTION}

Red tides, consisting of dense blooms of algae visible at the sea surface, can upset the balance of food webs and cause large-scale mortalities in fish and shellfish (e.g. Norris \& Chew 1975). Red tides in the coastal waters of southern California have been monitored since the early 1900s (Allen 1941). Gonyaulax polyedra Stein, Prorocentrum micans Ehrenberg and Gymnodinium sanguineum Hirasaka are the most common local red tide dinoflagellates, with concentrations often reaching more than $10^{6}$ cells $1^{-1}$ (Clendenning 1958, Holmes et al. 1967, Eppley \& Harrison 1975). Studies of red tide formation and persistence suggest that graz- ing pressure may sometimes play an important role in red tide dynamics (e.g. Watras et al. 1985). Some copepods and fish larvae are known to feed on some local red tide dinoflagellates (Lasker et al. 1970, Paffenhöfer 1976). Grazing by microzooplankton such as rotifers, tintinnids, and heterotrophic dinoflagellates is believed to contribute to the decline of blooms (Holmes et al. 1967, Eppley \& Harrison 1975).

Historical evidence from the coastal waters of southern California (Torrey 1902, Allen 1949) reveals that the heterotrophic dinoflagellate genus Protoperidinium may be very abundant during dinoflagellate blooms, and much less abundant during diatom blooms. Recently, high numbers of Protoperidinium 
were also associated with a red tide of Gonyaulax polyedra in La Jolla Bay during spring 1992 (Jeong unpubl. data). These observations suggest that Protoperidinium might have a considerable grazing impact on the populations of red tide dinoflagellates. Protoperidinium often dominates the protozoan biomass in coastal (Jacobson 1987) and oceanic waters of other regions (Lessard 1984)

Although most Protoperidinium species are known to feed on diatoms (Jacobson \& Anderson 1986, 1992, Buskey et al. 1992) and bacteria (Lessard \& Swift 1985, Lessard \& Rivkin 1986), several species have been observed feeding on dinoflagellates (Jacobson \& Anderson 1986, Hansen 1991). Protoperidinium does not engulf prey cells whole, but rather uses a tow filament to attach to a prey cell and then a pseudopod 'veil', called the pallium, to envelop the prey, with subsequent external digestion and pseudopod retraction (Gaines \& Taylor 1984, Jacobson \& Anderson 1986). This unique feeding mechanism suggests that prey selection by Protoperidinium may be different from that of grazers which swallow prey cells.

Pallium formation does not necessarily indicate that a prey type supports population growth of Protoperidinium. This is best determined by culturing on single algal prey species. Small species such as $P$. hirobis (23 $\mu \mathrm{m}$ diameter) and $P$. pellucidum (36 $\mu \mathrm{m}$ diameter) have been cultured on the diatoms Leptocylindrus danicus and Skeletonema costatum, respectively (Hansen 1992, Jacobson \& Anderson 1993). There are no reports of Protoperidinium cultured on dinoflagellate species, although Hansen (1991) observed $P$. divergens and $P$. pellucidum feeding on dinoflagellates in short-term enrichment cultures.

This study is the first report on the growth and grazing rates, and prey selection, of Protoperidinium feeding on dinoflagellate prey. It describes feeding of $P$. cf. divergens (Ehrenberg) Balech and P. crassipes (Kofoid) Balech collected from the pier at Scripps Institution of Oceanography and successfully cultured on mono- specific cultures of local red tide dinoflagellates, mainly Gonyaulax polyedra, Gymnodinium sanguineum and Scrippsiella trochoidea (Stein) Loeblich III. Both species exhibited maximal specific growth rates with $G$. polyedra as prey; $P$. cf. divergens offered mixed prey grazed preferentially on $G$. polyedra. This study provides a basis for understanding the interaction between Protoperidinium and red tide dinoflagellate prey.

\section{MATERIALS AND METHODS}

Culture of phytoplankton prey. Four species of autotrophic or mixotrophic dinoflagellates (Table 1) were grown in enriched $\mathrm{f} / 4$ seawater medium (Guillard \& Ryther 1962) without silicate, at room temperature $\left(20\right.$ to $\left.23^{\circ} \mathrm{C}\right)$ with continuous illumination of $100 \mu \mathrm{E} \mathrm{m}^{-2} \mathrm{~s}^{-1}$ of cool white fluorescent lights; cultures in exponential growth phase were used for feeding experiments. Cell size was measured with an Elzone model 280PC particle counter with a calibrated $120 \mu \mathrm{m}$ orifice.

Isolation and culture of Protoperidinium. Specimens of Protoperidinium were collected from the Scripps pier during October 1992 using a $35 \mathrm{~cm}$ diameter, $25 \mu \mathrm{m}$ mesh plankton net. Plankton samples were screened gently through $154 \mu \mathrm{m}$ Nitex mesh and placed in $1 \mathrm{l}$ glass bottles. After $2 \mathrm{~h}$ the upper three fourths of the volume was gently discarded and the remaining volume transferred into $250 \mathrm{ml}$ polycarbonate (PC) bottles. A mixture of Gonyaulax polyedra, Gymnodinium sanguineum and Scrippsiella trochoidea was added along with $50 \mathrm{ml}$ of $\mathrm{f} / 4$ medium. Bottles were placed on wheels rotating at 0.9 rpm under a $12: 12$ h light: dark cycle of illumination with $50 \mu \mathrm{E} \mathrm{m} \mathrm{m}^{-2} \mathrm{~s}^{-1}$ of cool white fluorescent light in a $19^{\circ} \mathrm{C}$ culture room. Five days later, aliquots of the enriched water were transferred into multi-well tissue culture plates containing freshly filtered seawater. Several large species of Protoperidinium were

Table 1 Species of heterotrophic dinoflagellates (last 2 taxa) and autotrophic or mixotrophic prey used in the present study, listed in order of size. Mean equivalent spherical diameter (ESD) \pm standard deviation of the mean for phytoplankton was measured by the Elzone 280PC particle counter, and for heterotrophic dinoflagellates by the equation: ESD $=(1 \mathrm{~W} h)^{1 / 3} \mathrm{where} I$ refers to cell length, $w=$ width, and $h=$ height. Volume (to the nearest $100 \mathrm{\mu m}^{3}$ ) was calculated according to the equation: volume $=4 / 3 \pi(\mathrm{ESD} / 2)^{3}$. The number of cells measured was $>5000$ for phytoplankton and $>50$ for Protoperidinium

\begin{tabular}{|lrr|}
\hline Species & ESD $(\mu \mathrm{m})$ & Volume $\left(\mu \mathrm{m}^{3}\right)$ \\
\hline Prorocentrum cf. balticum & $11.2 \pm 1.2$ & 700 \\
Scrippsiella trochoidea & $19.1 \pm 2.0$ & 3600 \\
Gymnodinium sanguineum & $31.7 \pm 3.2$ & 16700 \\
Gonyaulax polyedra & $36.7 \pm 3.0$ & 25700 \\
Protoperidinium cf. divergens & $61.0 \pm 2.8$ & 119000 \\
Protoperidinium crassipes & $73.0 \pm 4.9$ & 204000 \\
\hline
\end{tabular}


abundant. Of these $P$. cf. divergens $(73 \times 61 \times 52 \mu \mathrm{m}$; $61 \mu \mathrm{m}$ equivalent spherical diameter, ESD) and $P$. crassipes $(86 \times 80 \times 56 \mu \mathrm{m}, 73 \mu \mathrm{m}$ ESD) were selected for experimental work

Taxonomic authorities used to identify specimens were Balech (1988), Dodge (1982, 1985) and Taylor (1976) For identification, plate patterns and thecate forms of living, but motionless Protoperidinium on a slide were examined under a microscope. $P$. cf. divergens may be either $P$. divergens or $P$. brochii (Kofoid \& Swezy) Balech. The only difference between these 2 species is that the epitheca of $P$. divergens is more concave than in $P$. brochii.

Approximately 20 actively swimming individuals of each species were transferred into $32 \mathrm{ml} \mathrm{PC}$ centrifuge bottles. A mixture of Gonyaulax polyedra, Gymnodinium sanguineum and Scrippsiella trochoidea was added to each bottle as food. Alternatively, several diatom species, including Chaetoceros gracilis Schutt $(10 \mu \mathrm{m}$ ESD), C. decipiens Cleve $(13 \mu \mathrm{m}$ ESD for each cell of the chain), Leptocylindrus danicus Cleve (17 $\mu \mathrm{m}$ ESD for each cell of the chain), Skeletonema costatum (Greville) Cleve (17 $\mu \mathrm{m}$ ESD for each cell of the chain), and Thalassiosira weissflogii Grun (14 $\mu \mathrm{m}$ ESD) were provided as food. However, the diatom diet did not support growth of either Protoperidinium species, even though the presence of diatom cells within a pallium indicated that feeding was occurring

Bottles were placed on rotating wheels, maintained under controlled conditions as described above, and observed daily under a dissecting microscope to examine the swimming pattern and condition of Protoperidinium as well as food abundance. For the first $3 \mathrm{wk}$, actively swimming cells were individually transferred into new bottles containing freshly filtered seawater and algal mixture every 4 or $5 \mathrm{~d}$. After $3 \mathrm{wk}$, one-third of the bottle volume was transferred into new bottles. Once dense cultures of Protoperidinium were obtained they were maintained in 43 and $250 \mathrm{ml} \mathrm{PC}$ bottles.

Feeding process. To observe the feeding process, a dense culture of Protoperidinium cf. divergens was placed in multi-well tissue culture plates containing Gonyaulax polyedra cells. Many P. cf. divergens were observed under a dissecting microscope to immediately catch prey. Eight $P$. cf. divergens which had just made a pallium were individually transferred by a Pasteur micropipette into each well of multi-well tissue culture plates containing only freshly filtered seawater. The duration of the feeding process was recorded.

Growth of Protoperidinium cf. divergens and $P$. crassipes on red tide dinoflagellates. These experiments were designed to determine the species and concentration of local red tide dinoflagellates that would support maximum growth of Protoperidinium in culture. One predator species and one algal prey spe- cies were used in each experiment. More than $1 \mathrm{wk}$ prior to an experiment, high numbers of Protoperidinium cells from actively growing cultures were transferred into $43 \mathrm{ml} \mathrm{PC}$ bottles containing the test prey. During the preincubation period, Gonyaulax polyedra or Gymnodinium sanguineum at prey concentrations of approximately 500 and 1200 cells ml $\mathrm{m}^{-1}$ were used. The former concentration was used for experiments using $\leq 500$ cells $\mathrm{ml}^{-1}$, while the latter concentration was for experiments with $>500$ cells $\mathrm{ml}^{-1}$. Preincubations with Prorocentrum cf. balticum (Lohmann) Loeblich or Scrippsiella trochoidea were at a prey concentration of approximately $5000 \mathrm{cells} \mathrm{m}^{-1}$. There was evidence of no residual growth after preincubation because the growth rates of $P$. cf. divergens and $P$. crassipes were zero or less at low prey concentrations of $G$. polyedra and $G$. sanguineum and all tested concentrations of $P$. cf. balticum and $S$. trochoidea.

After a series of rinses by micropipette, large, fastswimming Protoperidinium (1 grazer $\mathrm{ml}^{-1}$, Expt 1 , or 7 to 10 grazers $\mathrm{ml}^{-1}$, Expt 2) were added to $32 \mathrm{ml} \mathrm{PC} \mathrm{bot-}$ tles containing freshly filtered seawater and different concentrations of algae. Each treatment was performed in duplicate or triplicate. Experiments in duplicate were repeated under identical conditions. Based on preliminary tests, the initial concentration series of

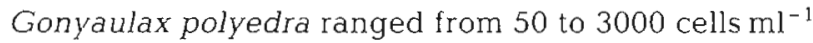
for $P$. cf. divergens experiments and 50 to 2000 cells $\mathrm{ml}^{-1}$ for $P$. crassipes. Initial concentrations of Gymnodinium sanguineum for both Protoperidinium species ranged from 50 to 2500 cells $\mathrm{ml}^{-1}$, and Prorocentrum cf. balticum and Scrippsiella trochoidea had initial concentrations of 500 to 12000 cells $\mathrm{ml}^{-1}$. In addition, 1.5 to $2.0 \mathrm{ml}$ of $\mathrm{f} / 4$ medium was added because preliminary tests indicated that this maintained final cell concentrations of $G$. polyedra and $G$. sanguineum in control bottles within $20 \%$ of initial concentrations. Once algal prey, medium, and Protoperidinium cells had been added, bottles were filled to capacity with filtered seawater using a Pasteur micropipette to minimize the bubble size that remained inside bottles after capping. Bottles were incubated for $4 \mathrm{~d}$ at $19^{\circ} \mathrm{C}$ as described above. This incubation period was chosen based on $P$. cf. divergens growth rate vs incubation time data, which will be detailed below.

Following incubation, final concentrations of prey cells in $1 \mathrm{ml}$ aliquots from experimental bottles were counted in triplicate using a Sedgwick-Rafter counting chamber. The remaining contents were transferred to multi-well tissue culture plates and the number of Protoperidinium counted under a dissecting microscope by removal with a Pasteur micropipette. Instantaneous feeding frequency was determined by counts of Protoperidinium cells with and without a pallium. 
The specific growth rate of Protoperidinium, $\mu\left(\mathrm{d}^{-1}\right)$, was calculated as:

$$
\mu=\frac{\ln \left(\frac{P_{t}}{P_{0}}\right)}{t}
$$

where $P_{0}=$ the initial concentration of Protoperidinium; and $P_{t}=$ the final concentration after time $t$.

In order to determine the relationship between estimated population growth rate and incubation time, 32 Protoperidinium cf. divergens cells $\left(1\right.$ grazer $\mathrm{ml}^{-1}$ ) were added to $32 \mathrm{ml} \mathrm{PC}$ bottles containing freshly filtered seawater, $2 \mathrm{ml} \mathrm{f/4}$ medium, and $1400 \mathrm{cells} \mathrm{ml}^{-1}$ of Gonyaulax polyedra. Two or three replicates for each day were incubated for 1 to $5 \mathrm{~d}$. Growth rate was calculated as described above.

Ingestion and prey selection. Because the highest specific growth rates of Protoperidinium were obtained with a diet of Gonyaulax polyedra, the ingestion rates of $P$. cf. divergens and $P$. crassipes fed on G. polyedra were measured. Initial concentrations of $G$. polyedra based on the results of the growth experiments were $100,300,700,1400,2000$, and 3000 cells $\mathrm{ml}^{-1}$ for $P$. cf. divergens ingestion studies, and 100,500,1000, 1500, and 2000 cells $\mathrm{ml}^{-1}$ for $P$. crassipes. Two initial concentrations of Protoperidinium were used, obtained by individually transferring cells by micropipette into triplicate $32 \mathrm{ml} \mathrm{PC}$ test bottles. At all but the lowest prey concentrations, 320 grazers (10 grazers $\mathrm{ml}^{-1}$ ) were added. At prey concentrations of 100 and 300 cells $\mathrm{ml}^{-1}$, only 224 grazers ( 7 grazers $\mathrm{ml}^{-1}$ ) were used, to minimize the depletion of prey. Control bottles contained only $G$. polyedra. In addition, 1.5 to $2.0 \mathrm{ml} / 4$ medium was added to each bottle. Bottles were incubated at $19^{\circ} \mathrm{C}$ for $4 \mathrm{~d}$ as described above. After incubation, the contents in experimental and control bottles were fixed with acidic Lugol's solution.

Ingestion rates were calculated using 2 different methods, one based on prey concentration, the other based on the abundance of round fecal aggregations of undigested compacted materials of prey. The conventional method (Method 1) compared final concentrations of prey in control and grazing bottles, measured by counting $1 \mathrm{ml}$ aliquots using a Sedgwick-Rafter counting chamber. More than 300 cells were counted in experiments with initial prey concentrations of 100 and 300 cells ml ${ }^{-1}$, and more than 500 cells at the other prey concentrations. The final concentration of Protoperidinium was obtained from counting the number of cells in a $6 \mathrm{ml}$ aliquot. Cell size of 20 grazers in each bottle was measured under an inverted microscope using an ocular micrometer. Using the equations of Frost (1972), the ingestion rate $I$ (prey ingested grazer $^{-1} \mathrm{~d}^{-1}$ ) was calculated as:

$$
I=\bar{C} F \times 24
$$

where $\bar{c}=$ the mean prey concentration; and $F=$ the clearance rate (volume grazer ${ }^{-1} \mathrm{~h}^{-1}$ ), calculated as:

$$
F=V g \bar{P}^{-1}
$$

where $V=$ the bottle volume; $g=$ the grazing constant $\left(\mathrm{h}^{-1}\right.$; see below); and $\bar{P}=$ the mean Protoperidinium number in the experimental bottles. The volumespecific clearance rate $\left(\mathrm{h}^{-1}\right)$, defined as volume cleared (body volume) $)^{-1} \mathrm{~h}^{-1}$, was also calculated. The mean prey concentration $\bar{C}$ is:

$$
\bar{C}=\frac{C_{0}\left(\mathrm{e}^{t(k-g)}-1\right)}{t(k-g)}
$$

where $C_{0}=$ the initial prey concentration in the experimental bottles; and $k=$ the prey growth constant $[k=$ $\ln \left(C_{t} / C_{0}\right) / t$, where $C_{t}=$ the final prey concentration in control bottles as a result of growth]. The grazing constant is calculated as:

$$
g=k-\frac{\ln \left(\frac{C_{t}^{*}}{C_{0}}\right)}{t}
$$

where the final prey concentration in the experimental bottles $\left(C_{t}^{*}\right)$ is the result of effects of grazing and growth:

$$
C_{t}^{*}=C_{0} \mathrm{e}^{t(k-g)}
$$

Based on Heinbokel (1978), the mean number of Protoperidinium in the experimental bottles, $\bar{P}$, was calculated as:

$$
\bar{P}=\frac{P_{0}\left(\mathrm{e}^{\mu t}-1\right)}{\mu t}
$$

where $P_{0}=$ the initial number of Protoperidinium.

Method 2, used to calculate ingestion rate, was based on the abundance of fecal aggregations produced following feeding, similar to the method of Jacobson \& Anderson (1993) to determine ingestion rates by counting empty diatom frustules after incubation. They observed that pallium formation resulted in frustules persisting during the incubation period. At the end of the feeding process the pallium detached, and only a round fecal aggregation of undigested compacted material, 15 to $20 \mu \mathrm{m}$ in diameter, remained. One prey ingested resulted in one fecal aggregation. Round fecal aggregations persisted due to the stickiness of the pallium and were readily distinguished from intact prey cells or other detritus. For experimental bottles, more than 50 fecal aggregations for prey concentrations of 100 and 300 cells ml-1 were counted, and more than 100 for the other prey concentrations. For Protoperidinium crassipes, ingestion rates were calculated by the second method only, because the low specific growth rate of $P$. crassipes did not result in significant changes in the final concentrations of prey between control and grazing bottles at high prey concentrations. 
Gross growth efficiency (GGE), defined as grazer biomass produced per prey biomass ingested, was calculated from estimates of carbon content per cell based on cell volume (Strathmann 1967). Ohman \& Snyder (1991) point out the bias that results if GGE is estimated directly from biovolumes.

Prey selectivity of Protoperidinium cf. divergens was investigated using a mixture of 2 algal species as food. 320 individuals of $P$. cf. divergens were added to $32 \mathrm{ml}$ $\mathrm{PC}$ bottles (10 grazers $\mathrm{ml}^{-1}$ ) containing different ratios of Gonyaulax polyedra and Gymnodinium sanguineum. Initial prey concentrations (cells $\mathrm{ml}^{-1}$ ) of $G$. polyedra and $G$. sanguineum (and the corresponding ratios of $G$. polyedra to total prey) were $333 / 1000$ (0.25), 500/500 $(0.50), 1000 / 1000(0.50)$ and $1000 / 333(0.75)$. The concentrations of $G$. sanguineum chosen supported optimal growth of $P$. cf. divergens populations based on unialgal studies. In addition to grazer and prey cells, 1.5 to $2.0 \mathrm{ml}$ of $\mathrm{f} / 4$ medium was added to each bottle. Bottles were incubated at $19^{\circ} \mathrm{C}$ for $4 \mathrm{~d}$ as described above. Ratios of ingestion rates of $P$. cf. divergens feeding on $G$. polyedra and $G$. sanguineum were calculated based on the difference in the final concentrations of prey in control and experimental bottles.

To determine the effect of prolonged starvation on survival and cell size of Protoperidinium, cultures were sieved though $54 \mu \mathrm{m}$ mesh to retain large cells, and transferred to a $250 \mathrm{ml}$ PC bottle containing filtered seawater without prey. Initial cell concentration was approximately 40 cells $\mathrm{ml}^{-1}$ and cell size was measured using the particle counter. Bottles were examined every $2 \mathrm{~d}$ under a dissecting microscope, and cell size was measured again after $12 \mathrm{~d}$ using the particle counter.

\section{RESULTS}

\section{Feeding process}

Protoperidinium were observed to feed on red tide dinoflagellates according to the mechanism described by Jacobson \& Anderson (1986), which involved deployment of a pallium which enveloped the prey cell. Once a Protoperidinium cell detected a suitable prey cell, it spun around the prey several times and caught the cell by deploying a tow filament. Two minutes later the length of the tow filament was shortened and the prey was attached to the posterior flagellar pore of Protoperidinium. Within $5 \mathrm{~min}$ a pallium had been deployed to envelop the prey; at this moment it was strong enough to resist detachment even when the Protoperidinium cell was transferred with a micropipette. Soon after the pallium formed the enveloped prey cell appeared to collapse as the cyto- plasm was digested. At the end of the feeding process the pallium detached from the grazer and only a round fecal aggregation of undigested compacted thecate material from the prey cell remained. These round fecal aggregations were readily distinguished from intact prey cells or other detritus. For Gonyaulax polyedra and Gymnodinium sanguineum prey, the diameters of the fecal aggregations were approximately $1 / 2$ and $1 / 3$, respectively, of the original size of the pallium. The duration of the entire feeding process was usually 38 to $60 \mathrm{~min}$, but could last more than $90 \mathrm{~min}$. During this time the Protoperidinium cell continued to swim; this behavior differed from that of Protoperidinium feeding on large chain-forming diatoms, where grazers often remained motionless and were unable to swim with the prey (Jacobson \& Anderson 1986). In many cases, a pallium containing a fecal aggregation was observed to detach prior to pallium retraction due to the swimming activities of the Protoperidinium. Fecal aggregations accumulated within the culture bottles.

\section{Growth of Protoperidinium cf. divergens}

Populations of Protoperidinium cf. divergens fed on Gonyaulax polyedra exhibited constant exponential growth for incubation periods as long as $4 \mathrm{~d}$ (Fig. 1A). There was a $1 \mathrm{~d}$ phase with reduced growth rate. This is similar to population growth of the heterotrophic dinoflagellate Oblea rotunda (Strom \& Buskey 1993), which shows constant exponential growth for $5 \mathrm{~d}$. In the present study, prey swimming activity did not change after the $4 \mathrm{~d}$ incubation, implying a healthy condition, but after $5 \mathrm{~d}$ this was observed to diminish. The growth rates calculated between time zero and either Day 3 or Day 4 (0.405 to $0.411 \mathrm{~d}^{-1}$ ) (Fig. 1B) compared favorably with the growth rate obtained from regression of ln-transformed cell abundance vs time for Days 1 to $4\left(0.477 \mathrm{~d}^{-1}\right)$.

The specific growth rate of Protoperidinium cf. divergens fed on Gonyaulax polyedra was dependent on mean prey concentration and perhaps influenced by initial grazer concentration (Fig. 2A). In general, specific growth rates increased with increasing mean prey concentration. The maximum specific growth rate at the lower initial grazer density $\left(1\right.$ grazer $\mathrm{ml}^{-1}$; Expt 1 ) averaged $0.484 \mathrm{~d}^{-1}$, obtained at a mean prey concentration of 1500 cells $\mathrm{ml}^{-1}$. At higher grazer concentrations ( 7 to 10 grazers $\mathrm{ml}^{-1}$; Expt 2), maximal specific growth rate was $0.363 \mathrm{~d}^{-1}$ at a mean prey concentration of 1100 cells $\mathrm{ml}^{-1}$. Specific growth rates for Expt 1 decreased at the highest mean prey concentration, while for Expt 2 they remained nearly saturated at mean prey concentrations above 1100 cells $\mathrm{ml}^{-1}$. The 

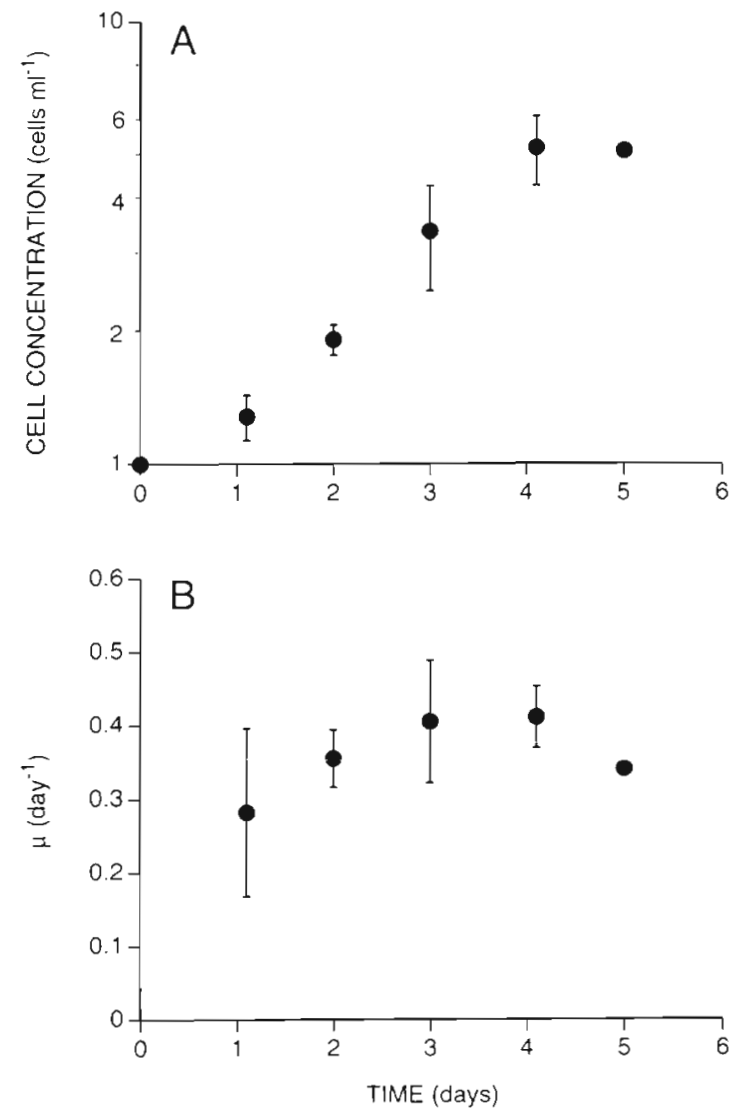

Fig. 1. Growth of Protoperidinium cf. divergens feeding on Gonyaulax polyedra at a prey concentration of 1400 cells $\mathrm{ml}^{-1}$ as a function of incubation time. Data are treatment means \pm 1 SE. (A) $P$ cf. divergens cell concentration over time. (B) Calculated $P$. cf. divergens population growth rates for corresponding incubation times

threshold mean prey concentration for population growth of $P$. cf. divergens in Expt 1 was approximately 70 to 100 cells ml ${ }^{-1}$.

Cannibalism occurred mainly at high grazer concentrations. Under these conditions, $P$. cf. divergens were observed with a pallium containing similarly sized cells of $P$. cf. divergens. The rate of cannibalism, and its effect on nutrition and growth, were not quantified in this study.

The specific growth rate of Protoperidinium cf. divergens feeding on Gymnodinium sanguineum exhibited a different pattern (Fig. 2B) from that for Gonyaulax polyedra. The threshold mean prey concentration for population growth of $P$. cf. divergens feeding on $G$.

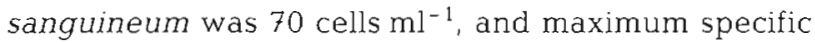
growth rate was $0.246 \mathrm{~d}^{-1}$ at a mean prey concentration of only 530 cells ml-1 At mean prey concentrations higher than 1000 cells ml-1 the specific growth rate declined, with negative values at mean prey concentrations greater than 2000 cells $\mathrm{ml}^{-1}$ An identical result was obtained in an additional experiment at the initial prey concentration of 2000 cells $\mathrm{ml}^{-1}$. Microscopic examination at the highest mean prey concentration confirmed the presence of dead $P$. cf. divergens cells.

The instantaneous feeding frequency was the proportion of the grazer population observed feeding at any one time, determined from the presence of prey within the pallium. The maximum instantaneous feeding frequency rather than mean instantaneous feeding frequency was tabulated because evidence for diel feeding periodicity was found at the conclusion of these experiments, and sampling was conducted at different times of day for the 2 species (Table 2). The maximum instantaneous feeding frequency was diet dependent. Up to $27 \%$ of Protoperidinium cf. divergens cells were observed feeding on Gonyaulax polye$d r a$, while a maximum frequency of $20 \%$ was obtained with a Gymnodinium sanguineum diet.
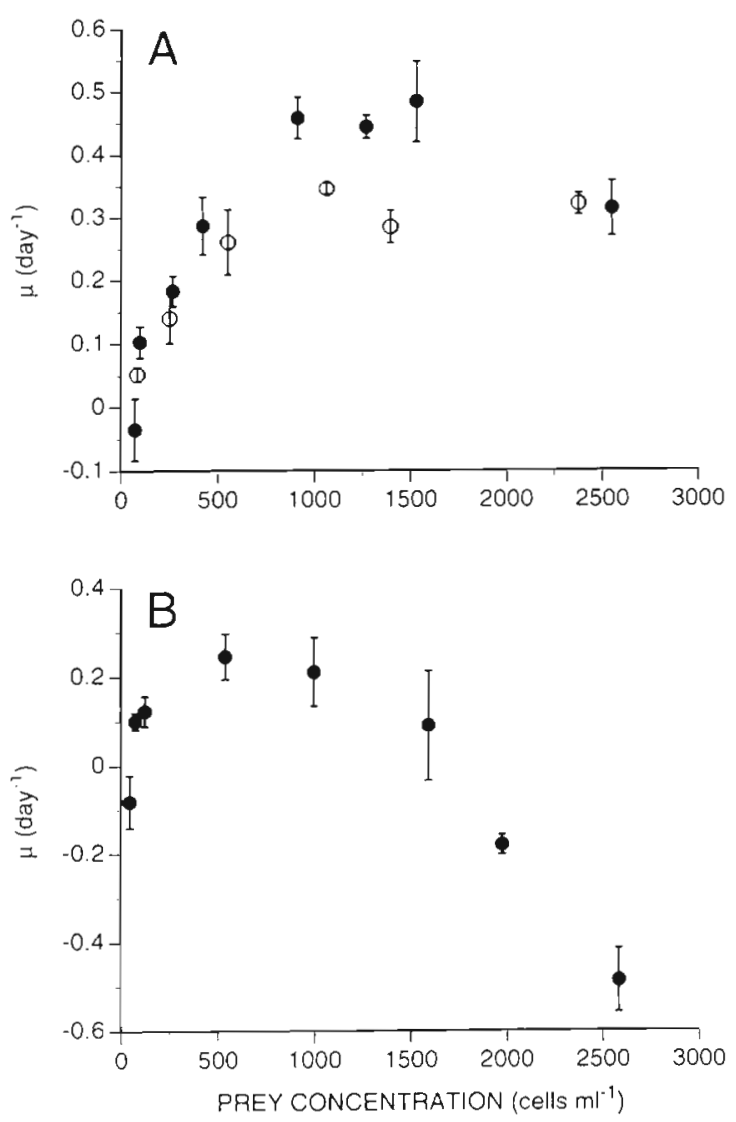

Fig. 2. Protoperidinium cf. divergens. Specific growth rate as a function of mean prey concentration. Data are treatment means $\pm 1 \mathrm{SE}$. (A) Gonyaulax polyedra prey. (O) Expt 1 (injtially 1 grazer $\mathrm{ml}^{-1}$ ); (O) Expt 2 (initially 7 grazers $\mathrm{ml}^{-1}$ at initial prey concentrations $\leq 300$ cells $\mathrm{ml}^{-1}$ and 10 grazers $\mathrm{ml}^{-1}$ at other initial prey concentrations). (B) Gymnodinıum sanguineum prey. Initial grazer concentration was 1 grazer $\mathrm{ml}^{-1}$ 
Table 2. Protoperidinium cf. divergens, P. crassipes. Maximum instantaneous feeding frequencies (MIFF), based on the percent ratio of Protoperidinium with a pallium to total grazers, for a variety of dinoflagellate prey. n: number of Protoperidinium observed

\begin{tabular}{|lrrrr|}
\hline & \multicolumn{2}{c}{ P. cf. divergens } & \multicolumn{2}{c}{ P. crassipes } \\
& MIFF & $\mathrm{n}$ & MIFF & $\mathrm{n}$ \\
\hline Gonyaulax polyedra & 27 & 7086 & 17 & 2474 \\
Gymnodinium sanguineum & 20 & 1782 & 5 & 734 \\
Scrippsiella trochoidea & 25 & 621 & 10 & 673 \\
Prorocentrum cf. balticum & 0 & 552 & 0 & 537 \\
\hline
\end{tabular}

Gonyaulax polyedra and Gymnodinium sanguineum were the only dinoflagellate prey tested that supported population growth of Protoperidinium cf. divergens. Other prey species tested were Scrippsiella trochoidea and Prorocentrum cf. balticum. Although $P$. cf. divergens were observed to feed on $S$. trochoidea, based on the presence of grazers with a pallium containing prey cells, the specific growth rate of $P$. cf. divergens fed on $S$. trochoidea was zero at prey concentrations between 1000 and 6000 cells ml $^{-1}$, and were negative for prey concentrations of 500 and $\geq 8000$ cells $\mathrm{ml}^{-1}$. The maximum instantaneous feeding frequency of $P$. cf. divergens feeding on $S$. trochoidea was similar to that for $G$. polyedra (Table 2), even though the specific growth rate for the former diet was zero. There were no observed differences in the size or swimming pattern of $P$. cf. divergens after feeding experiments with $G$. polyedra and S. trochoidea.

The specific growth rate of Protoperidinium cf. divergens fed on Prorocentrum cf. balticum was negative, and $P$. cf. divergens with a pallium were not observed in this treatment.

\section{Growth of Protoperidinium crassipes}

Generally, the pattern of specific growth rate as a function of mean prey concentration for Protoperidinium crassipes was similar to that of $P$. cf. divergens for each diet, although the rates were lower.

Protoperidinium crassipes fed Gonyaulax polyedra grew maximally at a mean prey concentration of 760 cells ml $^{-1}$ (Fig. 3A). At higher mean prey concentrations the specific growth rate decreased. At all mean

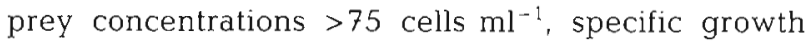
rates at the lower initial grazer concentration of 1 grazer $\mathrm{ml}^{-1}$ (Expt 3) were higher than those at the higher concentration of 7 to 10 grazers $\mathrm{ml}^{-1}$ (Expt 4). The maximum specific growth rate for Expt 3 was $0.308 \mathrm{~d}^{-1}$, while for Expt 4 it was $0.155 \mathrm{~d}^{-1}$ The threshold mean prey concentration for the population growth of $P$. crassipes for Expt 3 was approximately 70 to 90 cells $\mathrm{ml}^{-1}$, similar to that of $P$. cf. divergens.
Mainly at high grazer concentrations, cannibalism by P. crassipes on similar-sized cells was observed.

The specific growth rate of Protoperidinium crassipes fed on Gymnodinium sanguineum (Fig. 3B) exhibited a maximum of $0.107 \mathrm{~d}^{-1}$ at a mean prey concentration of $1050 \mathrm{cells} \mathrm{ml}^{-1}$, with a decrease at greater
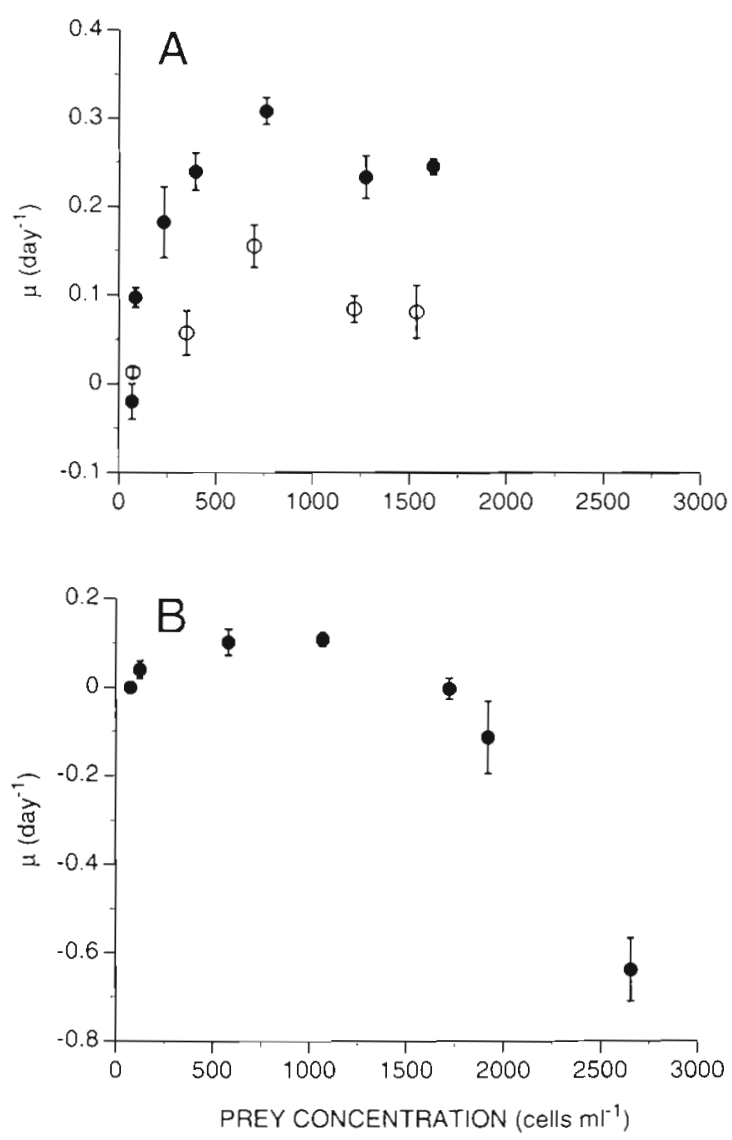

Fig. 3. Protoperidinium crassipes. Specific growth rate as a function of mean prey concentration. As in Fig. 2. (A) Gonyaulax polyedra prey. (O) Expt 3 (initially 1 grazer $\mathrm{ml}^{-1}$ ); (O) Expt 4 (initially 7 grazers $\mathrm{ml}^{-1}$ at an initial prey concentration of 100 cells $\mathrm{ml}^{-1}$ and 10 grazers $\mathrm{ml}^{-1}$ at the other initial prey concentrations). (B) Gymnodinium sanguineum prey. Initial grazer concentration was 1 grazer $\mathrm{ml}^{-1}$ 
concentrations. Specific growth rates were negative at mean prey concentrations $\geq 2000$ cells $\mathrm{ml}^{-1}$.

The maximum feeding frequencies of Protoperidinium crassipes on Gonyaulax polyedra, Gymnodinium sanguineum, and Scrippsiella trochoidea were lower than those of $P$. cf. divergens (Table 2). Even though $P$. crassipes fed on $S$. trochoidea, based on the presence of a pallium containing prey cells, specific growth rate was zero for this diet. A Prorocentrum cf. balticum diet did not support population growth of $P$. crassipes, nor did grazers make a pallium.

\section{Ingestion and clearance rates}

Ingestion rates calculated from final concentrations of prey in control and experimental bottles (Method 1) were consistently higher than those determined by enumerating fecal aggregations (Method 2). How long fecal aggregations persist is not known, although the evidence of Jacobson \& Anderson (1993) suggested that no degradation occurs due to the surrounding pallium. However, if some degrade during the incubation period then lower counts of fecal aggregations would be obtained. In any case, the pattern of ingestion rates as a function of mean prey concentration with both methods was similar (Fig. 4A). The ingestion rate of Protoperidinium of. divergens feeding on Gonyaulax polyedra increased with increasing mean prey concentration to a maximum of 4.8 prey grazer ${ }^{-1} \mathrm{~d}^{-1}$ for Method 1 and 3.5 prey grazer ${ }^{-1} \mathrm{~d}^{-1}$ for Method 2. Ingestion rates saturated at mean prey concentrations $\geq 1100$ cells $\mathrm{ml}^{-1}$ for both methods within the range tested. No threshold significantly different from 0 was found for either curve $(\mathrm{p}>0.05)$ using nonlinear regression (NLIN procedure; SAS 1990). Clearance rates determined by both methods decreased with increasing mean prey concentration (Fig. 4B). Maximum clearance rate for Method 1 was $0.67 \mu \mathrm{grazer}^{-1}$ $\mathrm{h}^{-1}$ and for Method 2 was $0.38 \mu$ grazer $^{-1} \mathrm{~h}^{-1}$. Maximum volume-specific clearance rate for Method 1 was $5.6 \times 10^{3} \mathrm{~h}^{-1}$ and for Method 2 was $3.2 \times 10^{3} \mathrm{~h}^{-1}$. The gross growth efficiency of $P$. cf. divergens fed on $G$. polyedra was 13.8 to $37 \%$ for Method 1 and 21.7 to $41.3 \%$ for Method 2.

Ingestion and clearance rates of Protoperidinium crassipes feeding on Gonyaulax polyedra as functions of mean prey concentration were based on Method 2 only. Because of the low specific growth rate of $P$. crassipes, differences in the final concentrations of prey between control and grazing bottles at high mean prey concentrations were not significant. Ingestion rate increased with mean prey concentration to a maximum of 2.1 prey grazer-1 $\mathrm{d}^{-1}$, reached at a mean prey concentration of 700 cells ml-1 (Fig. 5A). At higher mean prey concentrations there was a slight decrease in ingestion rate. Clearance rate decreased with mean prey concentration (Fig. 5B). Maximum clearance rate was $0.47 \mu$ grazer $^{-1} \mathrm{~h}^{-1}$. Maximum volume-specific clearance rate was $2.3 \times 10^{3} \mathrm{~h}^{-1}$. The gross growth efficiency of $P$. crassipes feeding on $G$. polyedra was 8.7 to $47.2 \%$.

The preference of Protoperidinium cf. divergens for a particular diet was determined from the ratio of ingestion rates for Gonyaulax polyedra and Gymnodinium sanguineum as a function of the ratio of the mean prey concentrations (Fig. 6A). All data points but one were above the $1: 1$ line, indicating that $P$. cf. divergens preferred $G$. polyedra to $G$. sanguineum. In these experiments the specific growth rate of $P$. cf. divergens was strongly correlated with the absolute concentration of G. polyedra (Fig. 6B).
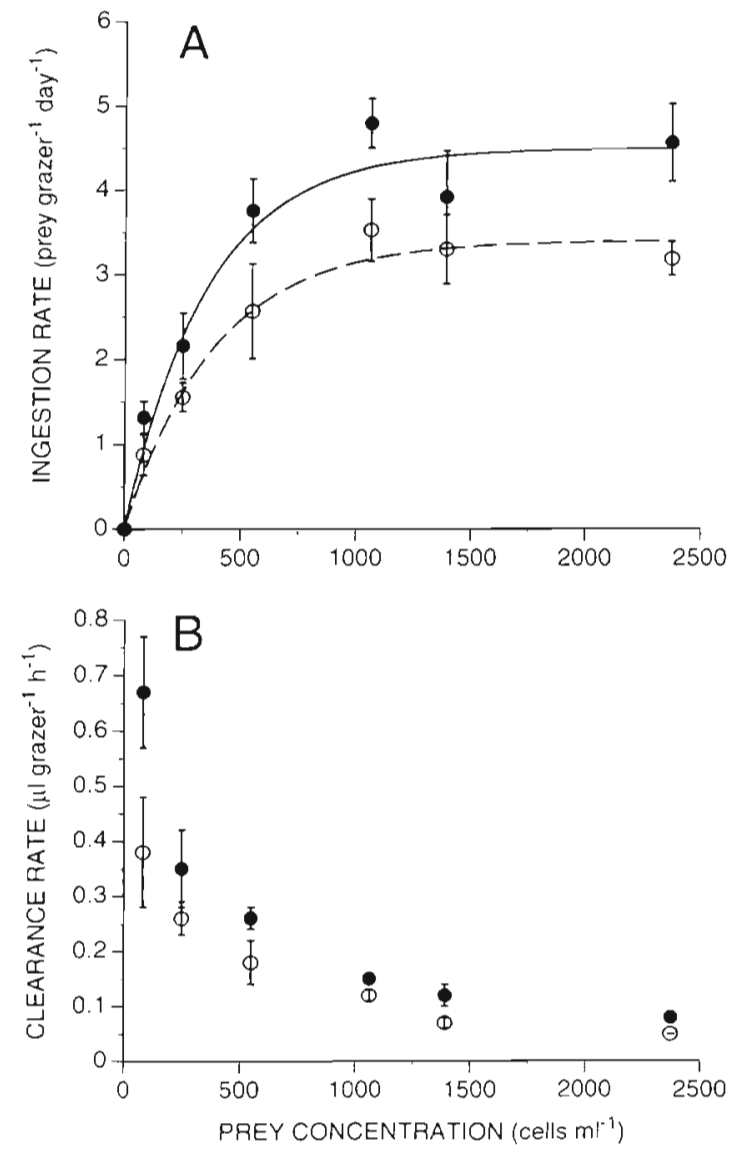

Fig. 4. Protoperidmium cf. divergens feeding on Gonyaulax polyedra. Data are treatment means $\pm 1 \mathrm{SE}$. (A) Ingestion rate as function of mean prey concentration). (-) Method 1 (see text); (O) Method 2. Both curves are fitted by the Ivlev model. Method 1: ingestion rate (IR, prey grazer-1 $\left.\mathrm{d}^{-1}\right)=4.5(1-$ $\left.e^{-000282 \bar{c}}\right), R^{2}=0.967 ;$ Method 2: $I R=3.4\left(1-e^{-0.00259 \bar{c}}\right), R^{2}=$ 0.964; where $\bar{c}=$ mean prey concentration. (B) Clearance rate as a function of mean prey concentration. (-) Method 1; (O) Method 2 

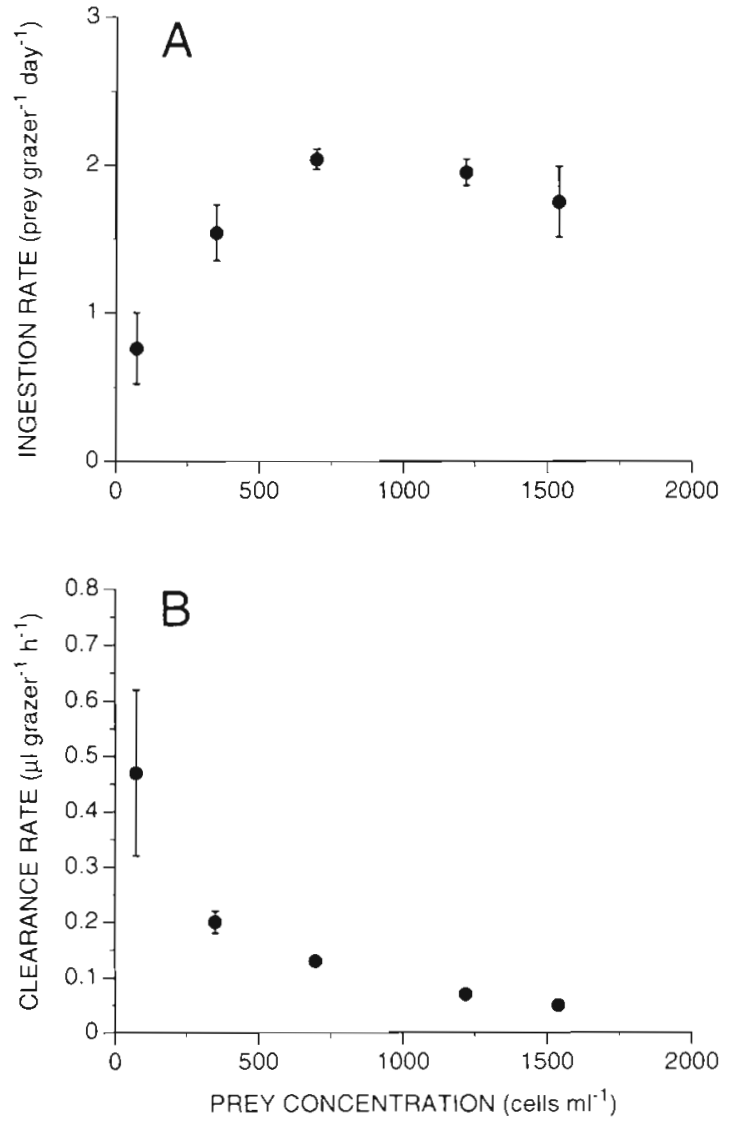

Fig. 5. Protoperidinium crassipes feeding on Gonyaulax polyedra. As in Fig. 4. (A) Ingestion rate as a function of mean prey concentration, based on enumeration of round fecal aggregations. (B) Clearance rate as a function of mean prey concentration, based on enumeration of round fecal aggregations

The size distribution of Protoperidinium cf. divergens changed from an initial range of 55.4-73.6 $\mu \mathrm{m}$ ESD (median $64.1 \mu \mathrm{m}$ ) to $11.2-75.4 \mu \mathrm{m}$ (median $14.93 \mu \mathrm{m}$ ) after $12 \mathrm{~d}$ without added prey. Some cells were observed swimming even after $15 \mathrm{~d}$ without added prey.

\section{DISCUSSION}

Populations of Protoperidinium cf. divergens and $P$. crassipes grow well in culture when maintained on unialgal diets of some local red tide dinoflagellates. This was expected because Protoperidinium has been observed to be very abundant during some local red tides (Torrey 1902, Allen 1949, Jeong unpubl. data). To date only $P$. pyriforme, $P$. divergens, and $P$. pellucidum have been described as feeding on dinoflagellates (Jacobson \& Anderson 1986, Hansen 1991). Most Protoperidinium species have been reported to feed on diatoms (Jacobson \& Anderson 1986, 1992, Buskey et al. 1992, Hansen 1992) and bacteria (Lessard \& Swift
1985, Lessard \& Rivkin 1986), even though the entire dietary range of any species has yet to be determined. During initial enrichment experiments, cells of other Protoperidinium species similar in size to and also smaller than the species tested were observed to produce a pallium and feed on the local red tide dinoflagellates Gonyaulax polyedra, Gymnodinium sanguineum, and Scrippsiella trochoidea.
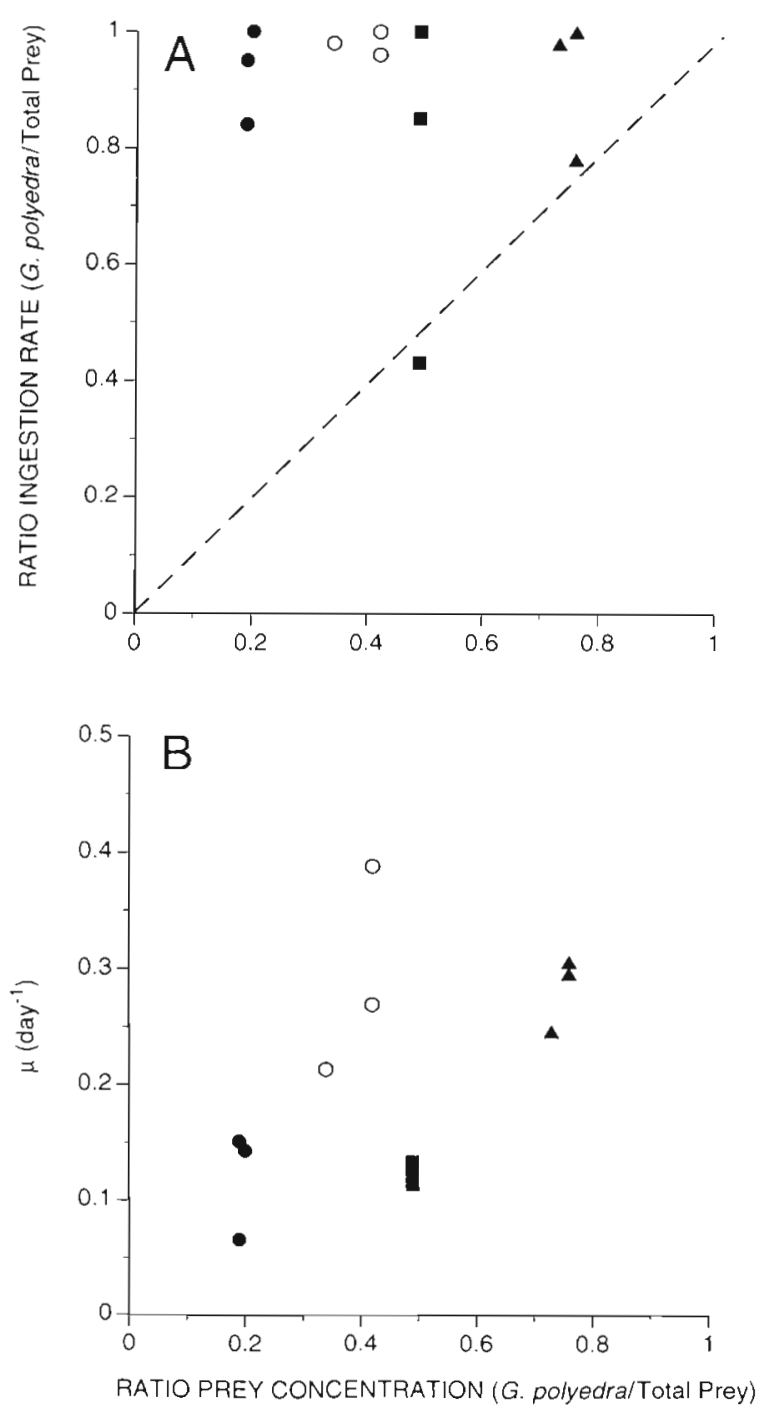

Fig. 6. Prey selection of Protoperidinium cf. divergens on a mixed diet of Conyaulax polyedra and Gymnodinium sanguineum. Each symbol represents the result of a single incubation bottle. (A) Ingestion of $G$. polyedra relative to ingestion of total prey ( $G$. polyedra and $G$. sanguineum), compared to relative availability of $G$. polyedra. Initial prey concentrations of $G$. polyedra and $G$. sanguineum, respectively, were 333 and 1000 cells ml $l^{-1}(0), 500$ and 500 cells ml $\mathbf{l}^{-1}$ ( ), 1000 and 1000 cells ml $\mathrm{m}^{-1}$ (O), and 1000 and 333 cells $\mathrm{ml}^{-1}(\mathbf{\Delta})$. (B) Specific growth rate of $P$. cf. divergens as a function of the ratio of $G$. polyedra to total mean prey concentration. Symbols as in (A) 
The larger dinoflagellates Gonyaulax polyedra and Gymnodinium sanguineum supported population growth of Protoperidinium cf. divergens and P. crassipes, while the smaller dinoflagellates Prorocentrum cf. balticum and Scrippsiella trochoidea did not. On the basis of growth rates and prey selection, for both grazer species $G$. polyedra was the optimal prey tested

The maximum specific growth rates $\left(\mu_{\max }\right)$ of Protoperidinium of divergens and $P$. crassipes were 0.484 and $0.308 \mathrm{~d}^{-1}$ at $19^{\circ} \mathrm{C}$, respectively, approximately 50 and $33 \%$ of those for ciliates of equivalent cell volumes at $20^{\circ} \mathrm{C}$ (Banse 1982 , Fenchel \& Finlay 1983), and $40 \%$ and $25 \%$ of that for the tintinnid ciliate Favella at $19^{\circ} \mathrm{C}$, which grows well on red tide dinoflagellates such as Gonyaulax polyedra, Gymnodinium sanguineum, and Scrippsiella trochoidea (Stoecker et al. 1981, Jeong unpubl. data). Hansen (1992) found a linear relationship between maximum growth rate and cell volume $\left[\log \mu\left(\mathrm{h}^{-1}\right)=-0.513-0.244 \log V\left(\mu \mathrm{m}^{3}\right)\right.$, where $V=$ cell volume] for some heterotrophic dinoflagellates with $<3 \times 10^{4} \mu^{3}$ cell volume. The $\mu_{\max }$ values for $P$. cf. divergens and $P$. crassipes $\left(1.2 \times 10^{5}\right.$ and $2 \times 10^{5} \mu \mathrm{m}^{3}$ in cell volume, respectively) obtained in the present study are similar to values calculated from this equation. Therefore the constant relationship of maximum growth rate to cell volume also is valid for much larger heterotrophic dinoflagellates.

The $\mu_{\max }$ values obtained for Protoperidinium cf. divergens and $P$. crassipes feeding on Gonyaulax polyedra and Gymnodinium sanguineum are similar to or larger than those of the prey populations (Thomas et al. 1973, Prézelin \& Sweeney 1978), as is true for small heterotrophic dinoflagellates and their prey (Goldman et al. 1989).

The specific growth rates of Protoperidinium cf. divergens and P. crassipes fed on Gymnodinium sanguineum were lower than for a Gonyaulax polyedra diet. This may be due to the lower carbon content of $G$. sanguineum compared to that of $G$. polyedra (Fernández 1979), and the lower maximum feeding frequencies on G. sanguineum compared to those of $G$. polyedra. The ratio of surface area to volume of $G$. sanguineum is $60 \%$ larger than for $G$. polyedra (Kamykowski et al. 1992). Therefore, Protoperidinium might spend more energy in pallium deployment on $G$. sanguineum than $G$. polyedra to gain the same carbon content for their growth.

For both grazers negative growth occurred at mean Gymnodinium sanguineum concentrations $>2000$ cells $\mathrm{ml}^{-1}$, and dead Protoperidinium were observed. Because high concentrations of Gonyaulax polyedra did not result in negative population growth, mechanical interference from the high number of prey cells may not be responsible. G. sanguineum has been demon- strated to be mixotrophic (Hellebust 1970, cited in Gaines \& Elbrächter 1987; Bockstahler \& Coats 1993), so perhaps when in high numbers $G$. sanguineum attacks the grazers, although $P$. cf. divergens and $P$. crassipes are much larger than the prey found inside vacuoles of $G$. sanguineum (Bockstahler \& Coats 1993). Alternatively, the toxicity of $G$. sanguineum may affect the growth of Protoperidinium. G. sanguineum has been reported to excrete toxic substances which inhibit the growth of fungi (Nagai et al. 1990). Additional experiments are needed to determine the mechanism responsible. In the field, Protoperidinium may avoid dense layers of $G$. sanguineum by regulating its vertical distribution, as do some copepods (Fiedler 1982).

The smaller dinoflagellate Scrippsiella trochoidea did not support population growth of Protoperidinium cf. divergens and $P$. crassipes, even though it was actively grazed by these species and was an excellent food for an unidentified small Protoperidinium species (slightly larger than Gonyaulax polyedra). This suggests, at least for this prey species, that feeding frequency was not an accurate indicator of prey suitability for long-term culturing. An $S$. trochoidea diet appears to fulfill routine energy requirements, but is insufficient to support population growth. There were no observed differences in size and swimming pattern of $P$. cf. divergens fed on $G$. polyedra and $S$. trochoidea after $4 \mathrm{~d}$ or $1 \mathrm{wk}$ incubations, and the bioluminescence of $P$. cf. divergens following a $4 \mathrm{~d}$ incubation with $S$. trochoidea was not significantly different from that after being maintained on a $G$. polyedra diet (Latz \& Jeong unpubl. data). This suggests that an $S$. trochoidea diet can maintain $P$. cf. divergens populations in a healthy condition with no net energy gain or loss.

The smallest prey used in this study, Prorocentrum cf. balticum, did not support population growth nor was there evidence of feeding based on pallium formation. However, Lessard \& Swift (1985) found evidence for ingestion of bacteria by Protoperidinium species similar in size to Protoperidinium cf. divergens and $P$. crassipes, although it is not known whether this was sufficient to support population growth.

Some studies have suggested that the most efficient feeding mechanism and maximum specific clearance are a function of predator-to-prey size ratio in flagellates and ciliates (Fenchel 1986, Goldman \& Dennett 1990). An optimal ratio for maximum growth rate may also be important in predator and prey population dynamics. Protoperidinium is a raptorial feeder and can feed on prey larger than itself. The growth rate of this heterotrophic dinoflagellate varied greatly depending on prey size. Based on data from this study, the maximum growth rate, $\mu_{\max }$ is negatively corre- 


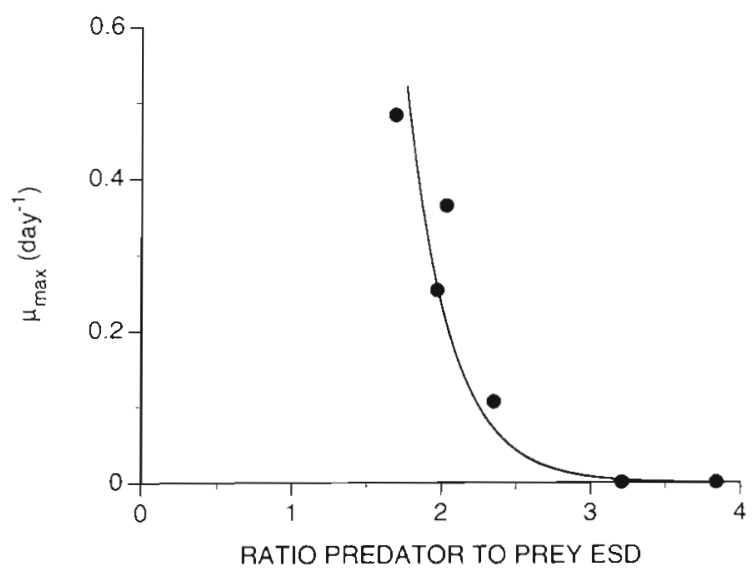

Fig. 7. Maximum growth rate, $\mu_{\max }$, of Protoperidinium cf. divergens and $P$. crassipes feeding on red tide dinoflagellate prey as a function of the ratio of predator-to-prey ESD. The least squares exponential regression is given as $\mu_{\max }=$ $200.89 e^{-3378 x}\left(R^{2}=0.93\right)$ for $x \geq 1.69$, where $x$ is the ratio of predator-to-prey ESD

lated with the ratio of predator-to-prey ESD for ratios $\geq 1.69$ (Fig. 7). Population growth of Protoperidinium occurs for a predator-to-prey size ratio $\leq 3$. The correlation between the maximum growth rate and ratio of predator-to-prey ESD suggests that the growth rates and feeding frequencies of $P$. crassipes might have been greater if it had fed on larger prey than those tested in this study. In preliminary tests, populations of P. depressum (Bailey) Balech (125 $\mu \mathrm{m}$ ESD), larger than $P$. crassipes, did not grow when fed on Gonyaulax polyedra, suggesting that they may require much larger sized prey.

Protoperidinium cf. divergens and $P$. crassipes fed on conspecific cells of similar size. Cannibalism was observed in cultures mainly when grazer populations were high. Cannibalism may be responsible for the maintenance of some large (ca $75 \mu \mathrm{m}$ ) cells of $P$. cf. divergens without added prey, even though median cell size decreases. Cannibalism may also be responsible for decreased growth rates obtained for higher initial grazer concentrations of 7 to 10 grazers $\mathrm{ml}^{-1}$. If this is true then the measured grazing rate may be overestimated.

The maximal instantaneous feeding frequency was $27 \%$ for a Gonyaulax polyedra diet, similar to the value of $30 \%$ obtained for Protoperidinium hirobis feeding on the diatom Leptocylindrus danicus (Jacobson \& Anderson 1993). Because the maximal instantaneous feeding frequency was not higher for smaller prey such as Scrippsiella trochoidea, these values may represent a maximal potential feeding frequency. Differences in specific growth rates for the various diets were not due to differences in feeding frequency.
There are few data on prey selection of heterotrophic dinoflagellates in mixtures of prey (Strom 1991). Protoperidinium were expected to exhibit prey selection due to their precapture behavior, which involves spinning around a target prey cell (Jacobson \& Anderson 1986). P. cf. divergens clearly preferred Gonyaulax polyedra over Gymnodinium sanguineum in mixed diets. Microscope observations confirmed that $P$. cf. divergens produced a pallium much more frequently with $G$. polyedra cells than with $G$. sanguineum. Even though the prey concentrations of $G$. sanguineum in these experiments were optimal for the growth of $P$. cf. divergens, the specific growth rate of $P$. cf. divergens on mixtures of $G$. polyedra and $G$. sanguineum was strongly correlated with an absolute concentration of $G$. polyedra. Ciliates also exhibit differential ingestion of prey not according to relative abundance, when a mixture of acceptable prey and less preferred prey is offered (Verity 1991).

Other microzooplankton have higher ingestion rates than Protoperidinium. The maximum ingestion rates of $P$. cf. divergens and $P$. crassipes fed on Gonyaulax polyedra, 0.2 and 0.08 prey Protoperidinium ${ }^{-1} \mathrm{~h}^{-1}$, respectively, were only 10 and $4 \%$, respectively, of that of the tintinnid ciliate Favella, which is approximately 2 prey Favella ${ }^{-1} \mathrm{~h}^{-1}$ (Jeong unpubl. data). Maximum clearance rates were slightly higher than that of $P$. hirobis feeding on Leptocylindrus danicus (Jacobson \& Anderson 1993), but much lower than the values for freshly collected $P$. divergens feeding on natural particles including bacteria (Lessard \& Swift 1985). Ingestion of bacteria may occur by a different feeding strategy not involving production of a pallium. Alternatively, differences in experimental methodology may explain differences in clearance rate, as suggested by Jacobson (1987).

The maximum grazing impact of microzooplankton during local red tides can be estimated based on the product of ingestion rate and grazer abundance. The ciliates Favella and Tiarina, as well as Protoperidinium, are associated with dinoflagellate red tides in the La Jolla area (Beers 1986, Jeong unpubl. data), and grow well feeding on the dinoflagellates Gonyaulax polyedra, Scrippsiella trochoidea, and Gymnodinium sanguineum (Stoecker et al. 1981, Jeong unpubl. data). The maximum growth rates of these ciliates are some 4 times higher than for Protoperidinium. However, the maximum abundances of Favella and Tiarina during local red tides (approximately 500 to 1000 ind. $1^{-1}$ for each genus; Jeong unpubl, data), are much less than that for Protoperidinium. For an ingestion rate of 0.2 prey grazer ${ }^{-1} \mathrm{~h}^{-1}$ and a grazer abundance of 24000 ind. $\mathrm{l}^{-1}$ (Allen 1949), the estimated impact on $G$. polyedra, 4800 prey ingested $\mathrm{l}^{-1} \mathrm{~h}^{-1}$, is more than double that of Favella, which has an ingestion rate of 2 prey grazer ${ }^{-1} \mathrm{~h}^{-1}$, an 
abundance of 1000 ind $\mathrm{l}^{-1}$, and a calculated impact of 2000 prey ingested $\mathrm{l}^{-1} \mathrm{~h}^{-1}$.

In the Southern California Bight, Protoperidinium is present in the plankton throughout the year (Allen 1949, Reid et al. 1970, Beers 1986). Several mechanisms may contribute to its maintenance during unfavorable prey conditions (Jacobson \& Anderson 1986 , present study):

(1) Populations can be maintained on a suboptimal diet even if it results in no net population growth. During initial tests, $P$. cf. divergens and $P$. crassipes were maintained on diatoms even though population growth did not occur. The maximum abundance of Protoperidinium during local diatom blooms is approximately 1200 ind $l^{-1}$ (Allen 1949), less than that during dinoflagellate red tides. In contrast, ciliates which feed on red tide dinoflagellates have a more limited dietary range and do not feed on diatoms (Stoecker et al. 1981).

(2) Protoperidinium, as well as other heterotrophic dinoflagellates, is able to resist starvation (Goodman 1987, Buskey et al. 1992, Hansen 1992, present study). In 2 experiments, $P$. cf. divergens was observed alive and swimming after $12 \mathrm{~d}$ without added prey. Favella is unable to resist starvation and dies within $3 \mathrm{~d}$ without food (Jeong pers. obs.), even though some ciliates can resist long starvation (Jackson \& Berger 1984).

(3) Protoperidinium feeds on conspecific cells in order to survive prolonged starvation as mentioned above. Cells presumably cannibalize unhealthy cells with impaired motility.

Cyst formation may be another mechanism used by dinoflagellates to survive periods of starvation (Goodman 1987). However, it is unknown if Protoperidinium uses cyst formation as a strategy for resisting starvation because at no time during the present study were cysts of Protoperidinium observed.

The ability to prey on a variety of food, including conspecific cells, and resistance to prolonged starvation, may allow Protoperidinium to maintain baseline populations at higher levels between blooms than do other microzooplankton grazers. This ability, coupled with population growth when suitable dinoflagellates are abundant, may explain the high abundance of Protoperidinium during red tides. Protoperidinium grazing may be important in regulating the populations of some red tide dinoflagellates, especially during the peak and decline of red tides.

Acknowledgements. We thank Michael Mullin, Mark Ohman, and Elizabeth Venrick for providing facilities and for comments on the manuscript. This paper was funded by a grant from California Sea Grant Graduate Fellowship Program, NOAA, U.S. Department of Commerce, (grant number NA89AA-D-SG138, project number E/G-10-6A) to H.J.J. and a grant from the Office of Naval Research (N00014-92-J-1475) to M.I.L.

\section{LITERATURE CITED}

Allen, W. E. (1941). Twenty years' statistical studies of marine plankton dinoflagellates of southern California. Am. Midl Nat. 26: 603-635

Allen, W. E. (1949). Data files, 1917 - 1949. Accession No. 8119. Scripps Institution of Oceanography Archives, University of California, San Diego

Balech, E. (1988). Los dinoflagelados del Atlantico Suboccidental. Publnes espec. Inst. Esp. Oceanogr. 1: 1-310

Banse, K. (1982). Cell volumes, maximal growth rates of unicellular algae and ciliates, and the role of ciliates in the marine pelagial. Limnol. Oceanogr. 27: 1059-1071

Beers, J. (1986). Organisms and the food web. In: Eppley, R. W. (ed.) Plankton dynamics of Southern California Bight. Springer-Verlag, New York, p. 104

Bockstahler, K. R., Coats, D. W. (1993). Spatial and temporal aspects of mixotrophy in Chesapeake Bay dinoflagellates. J. eukaryot. Microbiol. 40: 49-60

Buskey, E. J., Strom, S., Coulter, C. (1992). Bioluminescence of heterotrophic dinoflagellates from Texas coastal waters J. exp. mar. Biol. Ecol. 159: $37-49$

Clendenning, K. A. (1958). Red tide studies. In: The eftects of waste discharges on kelp. Annual Progress Report. University of California, Institute of Marine Resources, La Jolla, p. 37-38

Dodge, J. D. (1982). Marine dinoflagellates of the British Isles. Her Majesty's Stationery Office, London

Dodge, J. D. (1985). Atlas of dinoflagellates. Farrand, London

Eppley, R. W., Harrison, W. G. (1975). Physiological ecology of Gonyaulax polyedra, a red tide water dinoflagellate of southern California. In: Locicero, V. R. (ed.) Proceedings of the First International Conference on Toxic Dinoflagellate Blooms. Massachusetts Science and Technology Foundation, Wakefield, MA, p. 11-22

Fenchel, $T$ (1986). Protozoan filter feeding. In: Corliss, J. O., Patterson, D. J. (eds.) Progress in protistology, Vol. 1. Biopress, Bristol, p. 65-113

Fenchel, T. Finlay, B. J. (1983). Respiration rates in the heterotrophic, free-living Protozoa. Microb. Ecol. 9: 99-122

Fernández, F. (1979). Nutrition studies in the nauplius larva of Calanus pacificus (Copepoda: Calanoida). Mar. Biol. 53: $131-147$

Fiedler, P. C. (1982). Zooplankton avoidance and reduced grazing responses to Gymnodinium splendens (Dinophyceae). Limnol. Oceanogr. 27: 961-965

Frost, B. W. (1972). Effects of size and concentration of food particles on the feeding behavior of the marine planktonic copepod Calanus pacificus. Limnol. Oceanogr. 17: 805-815

Gaines, G., Elbrächter, M. (1987). Heterotrophic nutrition. In: Taylor, F J. R. (ed.) The biology of dinoflagellates. Blackwell, Oxford, p. 224-268

Gaines, G., Taylor, F. J. R. (1984). Extracellular digestion in marine dinoflagellates. J. Plankton Res. 6: 1057-1061

Goldman, J. C., Dennett, M. R. (1990). Dynamics of prey selection by an omnivorous flagellate. Mar. Ecol. Prog. Ser. 59: 183-194

Goldman, J. C., Dennett, M. R., Gordin, H. (1989). Dynamics of herbivorous grazing by the heterotrophic dinoflagellate Oxyrrhis marina. J. Plankton Res. 11: 391-407

Goodman, D. K. (1987). Dinoflagellate cysts in ancient and modern sediments. In: Taylor, F. J. R. (ed.) The biology of dinoflagellates. Blackwell, Oxford, p. 649-722

Guillard, R. R. L., Ryther, J. H. (1962). Studies of marine planktonic diatoms. I. Cyclotella nana Hustedt and Detonula confervacea (Cleve) Grun. Can. J. Microbiol. 8: 229-239 
Hansen, P.J. (1991). Quantitative importance and trophic role of heterotrophic dinoflagellates in a coastal pelagial food web. Mar. Ecol. Prog. Ser. 73: 253-261

Hansen, P. J. (1992). Prey size selection, feeding rates and growth dynamics of heterotrophic dinoflagellates with special emphasis on Gyrodinium spirale. Mar. Biol. 114: $327-334$

Heinbokel, J F. (1978). Studies on the functional role of tintinnids in the Southern California Bight. I. Grazing and growth rates in laboratory cultures. Mar. Biol. 47: $177-189$

Holmes, R. W., Williams, P. M., Eppley, R. W. (1967). Red water in La Jolla Bay, 1964-1966. Limnol. Oceanogr. 12 : 503-512

Jackson, K. M., Berger, J. (1984). Survival of ciliate protozoa under starvation conditions and at low bacterial levels. Microb. Ecol. 10: 47-59

Jacobson, D. M. (1987). The ecology and feeding biology of thecate heterotrophic dinoflagellates. Ph.D. thesis, Woods Hole Oceanographic Institution/Massachusetts Institute of Technology Joint Program, Woods Hole

Jacobson, D. M., Anderson, D. M. (1986). Thecate heterotrophic dinoflagellates: feeding behavior and mechanisms. J. Phycol. 22: 249-258

Jacobson, D. M., Anderson, D. M. (1992). Ultrastructure of the feeding apparatus and myonemal system of the heterotrophic dinoflagellate Protoperidinium spinulosum. J. Phycol. 28: 69-82

Jacobson, D. M., Anderson, D. M. (1993). Growth and grazing rates of Protoperidinium hirobis Abé, a thecate heterotrophic dinoflagellate. J. Plankton Res. 15: 723-736

Kamykowski, D., Reed, R. E., Kirkpatrick, G. J. (1992). Comparison of sinking velocity, swimming velocity, rotation and path characteristics among six marine dinoflagellate species. Mar. Biol. 111. 319-328

Lasker, R., Feder, H. M., Theilacker, G. H., May, R. C. (1970). Feeding, growth, and survival of Engraulis mordax larvae reared in the laboratory. Mar. Biol. 5: 345-358

Lessard, E. J. (1984). Oceanic heterotrophic dinoflagellates: distribution, abundance and role as microzooplankton. Ph.D. thesis, University of Rhode Island, Kingston

Lessard, E. J., Rivkin, R. B. (1986). Nutrition of microzooplankton and macrozooplankton from McMurdo Sound. Antarctic J. U.S. 21: $187-188$

Lessard, E. J., Swift, E. (1985). Species-specific grazing rates of heterotrophic dinoflagellates in oceanic waters, measured with a dual-label radioisotope technique. Mar. Biol. 87: $289-296$

Nagai, H., Satake, M., Murata, M., Yasumoto, T. (1990). Screening of marine phytoplankton for antifungal substances. In: Granéli, E., Sundström, B., Edler, L., Anderson,

This article was presented by D. K. Stoecker, Cambridge, Maryland, USA
D. M. (eds.) Toxic marine phytoplankton. Elsevier, New York, p. 385-390

Norris, L., Chew, K. K. (1975). Effects of environmental factors on growth of Gonyaulax catenella. In: Locicero, V. R. (ed.) Proceedings of the First International Conference on Toxic Dinoflagellate Blooms. Massachusetts Science and Technology Foundation, Wakefield, MA, p. 143-152

Ohman, M. D., Snyder, R. A. (1991). Growth kinetıcs of the omnivorous oligotrich ciliate Strombinium sp. Limnol. Oceanogr. 36: 922-935

Paffenhöfer, G. A. (1976). Continuous and nocturnal feeding of the marine planktonic copepod Calanus helgolandicus. Bull mar. Sci. 26: 49-58

Prézelin, B. B., Sweeney, B. M. (1978). Photoadaptation of photosynthesis in Gonyaulax polyedra. Mar. Biol. 48: $27-35$

Reid, F. M. H., Fuglister, E., Jordan, J. B. (1970). Part V. Phytoplankton taxonomy and standing crop. In: Strickland, J. D. H. (ed.) The ecology of the plankton off La Jolla, California, in the period April through September, 1967. Univ. Calif. Press, Berkeley, p. 51-66

SAS (1990). SAS/STAT user's guide, Vol. 2. SAS Institute. Raleigh, NC

Stoecker, D., Guillard, R. R. L., Kavee, R. M. (1981). Selective predation by Favella ehrenbergii (Tintinnida) on and among dinoflagellates. Biol. Bull. 160: 136-145

Strathmann, R. R. (1967). Estimating the organic carbon content of phytoplankton from cell volume or plasma volume. Limnol. Oceanogr. 12: 411-418

Strom, S. L. (1991). Growth and grazing rates of the herbivorous dinoflagellate Gymnodinium sp. from the open subarctic Pacific Ocean. Mar Ecol. Prog. Ser 78: 103-113

Strom, S. L., Buskey, E. J. (1993). Feeding, growth, and behavior of the thecate heterotrophic dinoflagellate Oblea rotunda. Limnol. Oceanogr. 38: 965-977

Taylor, F. J. R. (1976). Dinoflagellates from the international Indian Ocean expedition. E. Schweizerbart'sche Verlagsbuchhandlung, Stuttgart

Thomas, W. H., Dodson, A. N., Linden, C. A. (1973). Optimum light and temperature requirements for Gymnodinium splendens, a larval fish food organism. Fish. Bull. U.S. 71: $599-601$

Torrey, H. B. (1902). An unusual occurrence of dinoflagellata on the California coast. Am. Nat. 36: 187-192

Verity, P. G. (1991). Measurements and simulation of prey uptake by marine planktonic ciliates fed plastidic and aplastidic nanoplankton. Limnol. Oceanogr 36: 729-750

Watras, C. J., Garcon, V C.. Olson, R. J., Chisholm, S. W., Anderson, D. M. (1985). The effect of zooplankton grazing on estuarine blooms of the toxic dinoflagellate Gonyaulax tamarensis. J. Plankton Res. 7: 891-908

Manuscript first received: June 29, 1993

Revised version accepted: November 16,1993 